\title{
Pretreated Landfill Gas Conversion Process via a Catalytic Membrane Reactor for Renewable Combined Fuel Cell-Power Generation
}

\author{
Zoe Ziaka and Savvas Vasileiadis \\ Department of Catalysis and Environmental Protection, Hellenic Open University, 26335 Patras, Greece
}

Correspondence should be addressed to Zoe Ziaka; bookeng@hotmail.com

Received 5 December 2012; Accepted 8 March 2013

Academic Editor: Wei-Hsin Chen

Copyright (C) 2013 Z. Ziaka and S. Vasileiadis. This is an open access article distributed under the Creative Commons Attribution License, which permits unrestricted use, distribution, and reproduction in any medium, provided the original work is properly cited.

\begin{abstract}
A new landfill gas-based reforming catalytic processing system for the conversion of gaseous hydrocarbons, such as incoming methane to hydrogen and carbon oxide mixtures, is described and analyzed. The exit synthesis gas (syn-gas) is fed to power effectively high-temperature fuel cells such as SOFC types for combined efficient electricity generation. The current research work is also referred on the description and design aspects of permreactors (permeable reformers) carrying the same type of landfill gasreforming reactions. Membrane reactors is a new technology that can be applied efficiently in such systems. Membrane reactors seem to perform better than the nonmembrane traditional reactors. The aim of this research includes turnkey system and process development for the landfill-based power generation and fuel cell industries. Also, a discussion of the efficient utilization of landfill and waste type resources for combined green-type/renewable power generation with increased processing capacity and efficiency via fuel cell systems is taking place. Moreover, pollution reduction is an additional design consideration in the current catalytic processors fuel cell cycles.
\end{abstract}

\section{Introduction}

During our earlier IASTED papers (PGRES, '02, Marina Del Ray, CA; modeling and simulation, '03, Palm Springs, CA), we had the opportunity to describe and analyze preliminary results on catalytic processors for the steam-reforming reaction of methane and natural gas, for use in fuel cell systems such as SOFC units $[1,2]$.

The current paper is a continuation of that research effort by giving emphasis in the so-called "landfill gas power" and "bioenergy" systems. We study the use of landfill gases (landfill-generated feedstocks) as sources for electricity and heat generation using fuel cells of the SOFC type.

With the introduction of landfill-based gases rich in methane, for the production of intermediate synthesis gas we propose an attractive process in "green power" and "biogas/landfill energy" based systems.

A current emphasis on the development and commercialization of such systems for electricity and heat generation applications is observed. Such installations start to exist currently mainly in US, Europe, Japan, China, and other developing countries.

The above presented energy systems require the development and use of an effective catalytic reformer utilizing active metals such as $\mathrm{Ni}, \mathrm{Ru}, \mathrm{Rh}, \mathrm{Cr}$, or bimetallic combinations of those. Earth metal enrichment in the catalyst such as with $\mathrm{Ca}$, $\mathrm{Mg}, \mathrm{La}$, and $\mathrm{K}$ promotes the catalyst stability on stream and minimizes deactivation from carbon deposition, especially in the reactor inlet (deactivation propensity is especially high at the reactor inlet due to the lack of hydrogen gas which is generated during the course of the reaction) [3-9].

The aforementioned reformer can be a fixed-bed catalytic reactor or a permreactor using membrane-type materials as reactor walls. The introduction of a permreactor leads to a two-outlet reaction system which carries the synthesis gas product at different compositions. The permeate stream is richer in hydrogen and less rich in carbon oxides by the use of hydrogen selective membranes such as microporous inorganics (e.g., alumina, titania based) or metal alloys ( $\mathrm{Pd} / \mathrm{Ag}$, $\mathrm{Pd} / \mathrm{Cu}$ ). Moreover, one or both of the outlet gas streams 
can be used as feed in the accompanied fuel cell/SOFC. The utilization of the permreactor increases the conversion of the reactant landfill gases in the reactor due to the separation of products. This increased shift in conversion yields the required quantity of synthesis gas product for the fuel cell at a lower operation temperature than the counterpart fixedbed (impermeable) reactor $[10,11]$. Process operation at a lower temperature is beneficial for increasing the reactor and catalyst life times and for reducing the endothermic heating load (Btu/hr) of the endothermic reformer.

Following, we present a design with emphasis in both reformer configurations for the generation and delivery of hydrogen-rich synthesis gas from landfill gas resources into the accompanied solid oxide fuel cell.

\section{Process and Fuel Cell Analysis and Description}

The catalytic reaction of reforming methane or higher hydrocarbons with the steam is a key catalysis process for producing high-quality hydrogen or synthesis gas in an economical way $[3-6,8,12,13]$. As it is known, synthesis gas contains hydrogen mixed with carbon monoxide and possibly carbon dioxide as well. The aforementioned reforming processes are endothermic taking place under similar catalysis metals as those described before.

Utilization of landfill-based feedstocks, as the reacting gases, provides a methane- $\left(\mathrm{CH}_{4}^{-}\right)$rich feed in the reformer which is converted with steam into an $\mathrm{H}_{2}$ - and $\mathrm{CO}$-rich mixture. Moreover, the exit hydrogen-rich gas is going as fuel in the anode of the solid oxide fuel cell. The reactions below take place in the reformer by adding steam in the landfill feedstock as the oxidant, as shown:

$$
\mathrm{CH}_{4}+\mathrm{H}_{2} \mathrm{O} \longleftrightarrow \mathrm{CO}+3 \mathrm{H}_{2} \quad\left(\Delta \mathrm{H}_{298}^{\mathrm{o}}=+206.1 \mathrm{~kJ} / \mathrm{mol}\right)
$$

(methane-steam reforming reaction)

$$
\mathrm{CO}+\mathrm{H}_{2} \mathrm{O} \longleftrightarrow \mathrm{CO}_{2}+\mathrm{H}_{2} \quad\left(\Delta \mathrm{H}_{298}^{\mathrm{o}}=-41.15 \mathrm{~kJ} / \mathrm{mol}\right)
$$

(water-gas shift reaction)

However, it is assumed that the landfill gas has been purified before entering into the reformer from the various impurities and the contained carbon dioxide gas. The carbon dioxide gas can be separated using several options such as membrane-based separations or pressure-swing adsorption $[10,11]$. However, some $\mathrm{CO}_{2}$ can be flown within the reactor and reformed catalytically with the methane.

In continuation, the interconnected solid oxide fuel cell (SOFC) produces electricity by the following dual electrochemical reaction,

In the SOFC anode:

$$
\begin{gathered}
\mathrm{H}_{2}+\mathrm{O}^{2-} \longrightarrow \mathrm{H}_{2} \mathrm{O}+2 \mathrm{e}^{-} \\
\mathrm{CO}+\mathrm{O}^{2-} \longrightarrow \mathrm{CO}_{2}+2 \mathrm{e}^{-}
\end{gathered}
$$

In the SOFC cathode:

$$
\mathrm{O}_{2}+4 \mathrm{e}^{-} \longrightarrow 2 \mathrm{O}^{2-}
$$

The overall reaction is

$$
\mathrm{H}_{2}+\mathrm{CO}+\mathrm{O}_{2} \longrightarrow \mathrm{CO}_{2}+\mathrm{H}_{2} \mathrm{O}
$$

A portion of the hot gas exiting from the fuel cell can be diverted in the shellside of the membrane reactor to provide the endothermic heat for running the reformer.

The corresponding mathematical modeling of the methane-steam reformer for a steady-state fixed-bed catalytic reactor, including the species reaction terms in the mass balance equation, is as it is presented:

$$
\frac{d X^{A}}{d z}=\left(\frac{\pi d_{T}^{2}}{4 n_{A_{o}}}\right) \rho_{B} R_{A} .
$$

Species $A$ can be any of the reactants and products of the reactions (1) and (2),

with

$$
\begin{gathered}
R_{\mathrm{CH}_{4}}=-R_{1}, \\
R_{\mathrm{CO}_{2}}=R_{2}, \quad R_{\mathrm{CO}}=R_{1}-R_{2}, \\
R_{\mathrm{H}_{2}}=3 R_{1}+R_{2}, \quad R_{\mathrm{H}_{2} \mathrm{O}}=-R_{1}-R_{2},
\end{gathered}
$$

where $R_{1}$ and $R_{2}$ are the heterogeneous reaction rates of the reactions (1) and (2) given above.

In addition, the thermal balance in a nonisothermal reformer is given as follows:

$$
\begin{aligned}
& \frac{d T_{T}}{d z} \\
& =\left(\frac{\pi d_{T}^{2}}{4}\right)\left(\frac{1}{m^{\prime} c_{p}}\right)\left\{\rho_{B}\left[\left(-\Delta H_{r}^{1}\right) R_{1}+\left(-\Delta H_{\mathrm{r}}^{2}\right) R_{2}\right]\right. \\
& \left.-4\left(\frac{U}{d_{T}}\right)\left(T_{T}-T_{S}\right)\right\} .
\end{aligned}
$$

Moreover, the reformer pressure balance which describes the pressure drop along the fixed bed of catalyst is given as follows:

$$
\frac{-d P_{T}}{d z}=\frac{2 f \rho_{g} u_{s}^{2}}{g_{c} d_{p}}
$$

and the above equations are complemented by initial conditions as shown: at $z=0$ (reactor inlet),

$$
X^{A}=0, \quad T_{T}=T_{o}, \quad P_{T}=P_{T_{o}} .
$$

A more specific analysis of the model, its parameters, and their variation is discussed in earlier communications [1012].

The above system of governing (6), (8), and (9) is integrated numerically as an initial value problem to provide the reactant conversions, product yields, reactor temperature, and pressure along the axial length and to obtain the axial profiles of these variables and their values at the reactor exit.

With the use of an inorganic permreactor as the main catalytic processing unit to convert landfill gas feedstocks 
into fuel cell gas, the above design equations are modified accordingly to include the permeation effects via the membrane of the different components. Moreover, the following mathematical part has to be added at the right hand side of (6) to account for the permeation effects within the mass balance equations:

$$
-\left(\frac{2 \pi}{n_{A_{o}}^{T}}\right) P_{A, e}\left[\frac{p_{A}^{T}-p_{A}^{S}}{\ln \left(r_{1} / r_{2}\right)}\right],
$$

wherein $P_{A, e}(\mathrm{gmol} / \mathrm{s} \cdot \mathrm{cm} \cdot \mathrm{atm})$ is the effective permeability coefficient of species $A$ via the catalytic or noncatalytic (blank) membrane. It is worthy to declare that in our earlier experimental reaction studies we utilized mesoporous aluminum oxide membranes having a thin permselective layer (3-5 $\mu \mathrm{m}$ thickness, $50 \%$ porosity) with $40-50 \AA$ pore diameter $[3,10,11,14]$. The membrane is a multilayer structure supported on an a-alumina support $(1.5-2.0 \mathrm{~mm}$ thickness, $40-45 \%$ porosity, and $10-15 \mu \mathrm{m}$ pore diameter). When a permreactor is used, the corresponding mass, temperature, and pressure variation equations are written as well for the gas which permeates via the membrane wall material and flows in the permeate side $(S)$ of the membrane reactor. It is assumed that there are no reactions occurring in the permeate membrane side. An analysis of the model for the permreactor has been described as well in earlier communications [10-12].

By employing (6), (8), (9), and (11) within the modeling procedure, a complete reactor analysis is obtained for the two different reformer configurations. Solution of the equations is obtained numerically by using an initial value integration technique for ordinary differential equations with variable stepsize to ensure higher accuracy (implicit Adams-Moulton method) [10, 11].

In our earlier papers, we have described and analyzed the reaction, separation (i.e., permeation), and process (conversion, yield) characteristics of permreactors (membrane based catalytic reactors) and related processes for methanesteam reforming, water-gas shift, and methane carbon dioxide reforming reactions including catalysis and membrane materials characteristics. The main categories of reactors described were membrane reformers which were utilized as single permreactor [10], permreactor-separator in series or reactor-separator in series and permeactor-permeactor in series $[3,10,13,14]$.

These effective and versatile catalytic processes were applied for pure hydrogen $\left(\mathrm{H}_{2}\right), \mathrm{H}_{2}$ and $\mathrm{CO}_{2}$, or $\mathrm{H}_{2}$ and $\mathrm{CO}$ (syn-gas) generation to be used as fuel gas for power generation or as synthesis gas for the production of specialty chemicals (such as methanol and higher hydrocarbons) [10]. Several key types of membrane reformers were examined based on the location of the fixed catalytic bed and the inert or catalytic nature of the inorganic (alumina-based) membrane tube. Computational modeling of the described permreformers was running indicating performance measures (reactant conversion, product yield) versus variation of intrinsic model parameters (reactor space time, reaction temperature, and pressure, feed composition, sweep gas to feed gas ratio). Through the models, we also obtain performance measures
TABLE 1: Specifications of a representative small landfill gasreforming SOFC system, for electricity and heat cogeneration.

\begin{tabular}{lc}
\hline Landfill gas production volume: & $3,600 \mathrm{~m}^{3} /$ day \\
Methane production volume/about: & $2,520 \mathrm{~m}^{3} \mathrm{CH}_{4} /$ day \\
Total energy generation: & $26,100 \mathrm{kWh} /$ day \\
Electricity generation/SOFC (60\% min): & $15,660 \mathrm{kWh} /$ day \\
Heat generation (30\% min): & $7,830 \mathrm{kWh} /$ day \\
Waste heat (about 10\%): & $2,610 \mathrm{kWh} /$ day \\
Annual electricity generation: & $5,716 \mathrm{MWh} /$ year \\
Sale price per MWh (to DEH, Greek & $73 \mathrm{Euro} / \mathrm{MWh}$ \\
Electricity Authority) & $417,000 \mathrm{Euro} /$ year \\
Income about: & $2,858 \mathrm{MWh} /$ year \\
Annual heat generation: &
\end{tabular}

under new operating conditions leading to new energy and chemical process applications $[3,10,14]$.

Moreover, the interconnected or integrated solid oxide fuel cell is fed directly by the fuel gas generated by the described reformers. The focus of our studies goes to solutions in a number of problems associated with the installation, operation, and mass energy conservation of the entire fuel cell and membrane-processing unit.

The economic feasibility of the overall fuel cell installation is correlated with high efficiency (e.g., $45 \%-65 \%$ for advanced units) and high current density output $\left(\mathrm{A} / \mathrm{cm}^{2}\right)$, increased system reliability for continuous dispersed power generation, and reduced plant installation, operation, and maintenance cost. Such goals combined with virtual elimination of pollution by the use of fuel cells in stationary (e.g., central and remote power stations) and mobile/transportation (e.g., automobile) sources make this technology highly applicable and attractive. Finally, clean fuel cell power minimizes NOx, $\mathrm{CO}$, and hydrocarbon species in the emissions.

\section{Results and Discussion}

Proper utilization of landfill gas in the reformer coming from landfill sites presents an innovative approach for direct use of those feedstocks for power generation [15]. There are essential resources of these feedstocks today, and their accumulation in land is growing. Gas coming out from the proper treatment of landfills and from municipal sewage and sludge sites is rich in methane and constitutes the proper mixture for direct conversion into the described reformerSOFC system. Through the catalytic conversion of these gases in the reformer we can obtain yields of hydrogen-rich mixture for properly powering the interconnected SOFC. As the flow rates of the landfill gas increase (for larger sites and treatment systems), a larger capacity reformer and fuel cell are required to handle the conversion; consecutively, the final SOFC power output $\left(\mathrm{kW} / \mathrm{cm}^{2}\right)$ increases as well.

The catalyst used in the experiments described below is a $15 \% \mathrm{NiO}$ mixed with calcium and magnesium and supported on alumina. The catalyst characteristics are shown in Table 3. 
TABLE 2: Membrane characteristics.

\begin{tabular}{lcc}
\hline Layer & Pore diameter & Thickness \\
\hline 1 & $40 \AA$ & $5 \mu \mathrm{m}$ \\
2 & $0.20 \mu \mathrm{m}$ & $30 \mu \mathrm{m}$ \\
3 & $0.8 \mu \mathrm{m}$ & $50 \mu \mathrm{m}$ \\
4 support & $10-15 \mu \mathrm{m}$ & $1.5-2.0 \mathrm{~mm}$ \\
\hline
\end{tabular}

TABLE 3: Catalyst characteristics.

\begin{tabular}{lc}
\hline Pore volume & $0.3 \mathrm{cc} / \mathrm{g}$ \\
Surface area & $50 \mathrm{~m}^{2} / \mathrm{g}$ \\
Porosity & $55 \%$ \\
Composition & $15 \% \mathrm{wt}$ \\
\hline
\end{tabular}

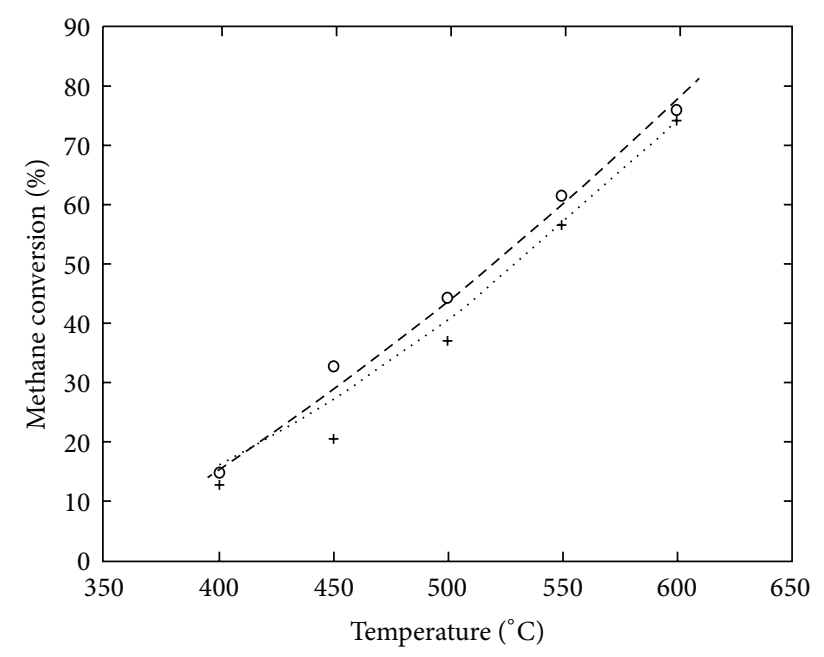

- Membrane reactor experiment, sweep Ar: 0.11 gmole/hr

- - Membrane reactor model

$+\quad$ Plug flow reactor experiment Equilibrium conversion

FIGURE 1: Experimental and modeling results of landfill gas-steam reformers for syngas production and SOFC continuous operation. Total methane conversion data $\left(P_{T_{o}}=1.68 \mathrm{~atm}\right.$, space time $=$ $\left.48.0 \mathrm{~g}_{\text {cat }} \cdot \mathrm{hr} / \mathrm{gmole}_{\mathrm{CH} 4}\right)$.

The system of the apparatus used in the experiments reported here consists of mass-flow controllers, a bubbler to generate steam for the reaction, and the reactor housing wherein the plug-flow reactor or the membrane reactor was placed. The reactor is accompanied with thermocouples to read the temperature and pressure transducers to read the pressure. At the exit of the reactor apparatus there are steam traps and a gas chromatograph to analyze the exit stream. The gas chromatograph operates in the TCD mode and is equipped with a porapack Q column for the gas analysis.

Figure 1 below describes a set of experiments for the two reformer configurations. The membrane reformer shows better methane conversions than the nonmembrane reformer for all the range of temperatures examined experimentally (i.e., $400-600^{\circ} \mathrm{C}$ ). At low temperatures, we avoid coke formation and prolong the catalyst activity. The membrane characteristics are shown in Table 2.

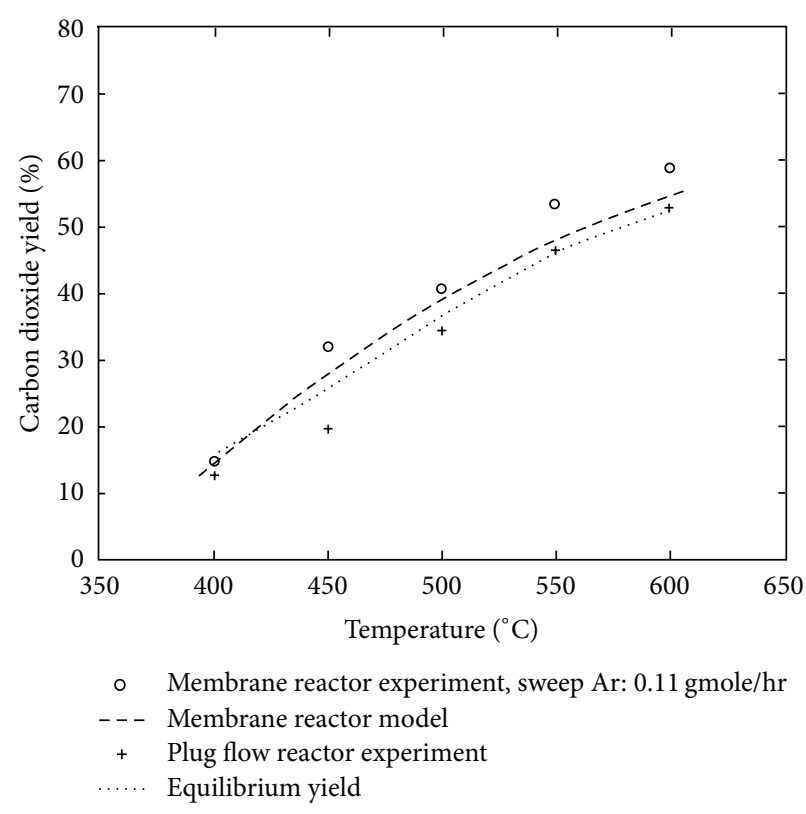

FIGURE 2: Experimental and modeling results of landfill gas-steam reformers for syngas production and SOFC continuous operation. Carbon dioxide yield data $\left(P_{T_{0}}=1.68 \mathrm{~atm}\right.$, space time $=$ $\left.48.0 \mathrm{~g}_{\mathrm{cat}} \cdot \mathrm{hr} / \mathrm{gmole}_{\mathrm{CH} 4}\right)$.

Ar gas was flown in the permeate side of the membrane reactor to sweep the permeating gas. The feed composition is $\mathrm{CH}_{4}: \mathrm{H}_{2} \mathrm{O}: \mathrm{H}_{2}=1: 4: 0.20$. The residence time of the reactor remained constant at $48.0 \mathrm{~g} \cdot \mathrm{hr} / \mathrm{gmol}_{\mathrm{CH} 4}$ for all the experiments reported here. The pressure at the reaction side was kept constant at $P_{T}=10 \pm 0.5 \mathrm{psig}$. There is also a good agreement of the developed model with the experimental membrane-reactor conversions. Moreover, most of the conversions obtained with the membrane reformer are better than the ones calculated at the equilibrium state.

The equilibrium calculations are based on the maximum thermodynamic equilibrium conversion that the specific reaction system can achieve according to the operating parameters and conditions given. They are calculated by the corresponding thermodynamic equilibrium equations. The results are shown in the figures as equilibrium yields and conversions. The permeability (permeability coefficient $x$ $10^{2}, \mathrm{~mol} / \mathrm{m} \cdot \mathrm{s} \cdot \mathrm{Pa}$ ) is given in Table 4 . They are experimental measurements at $35^{\circ} \mathrm{C}$ for unmodified alumina membrane.

The reactor is a tubular one with the ceramic membrane inside. Its length is $20 \mathrm{~cm}$, and the diameter is $1 \mathrm{~cm}$, with feed flow rate 0.11 gmole/hr. The reactor schematic is shown in Figure 8.

Figure 2 is indicative of the carbon dioxide yields obtained with the membrane reformer as function of the reaction temperature. These yields are better than those obtained with the nonmembrane type reformer and the equilibrium calculated yields. The results of Figure 2 are indicative of the yield of the water-gas shift reaction (reaction (2)). However, our future efforts seek to minimize the effect of reaction (2) and promote the effect of reaction (1) only. In 
TABle 4: Permeability coefficient $\times 10^{2}$, mol/m.s.Pa. Experimental measurements at $35^{\circ} \mathrm{C}$ for unmodified alumina membrane.

\begin{tabular}{|c|c|c|c|c|c|}
\hline Average transmembrane pressure, $\mathrm{KPa}$ & Hydrogen & Methane & Carbon monoxide & Carbon dioxide & Argon \\
\hline 105 & 168 & 76 & 54 & 50 & 42 \\
\hline 117 & 179 & 81 & 57 & 56 & 45 \\
\hline 135 & 181 & 83 & 60 & 59 & 52 \\
\hline
\end{tabular}

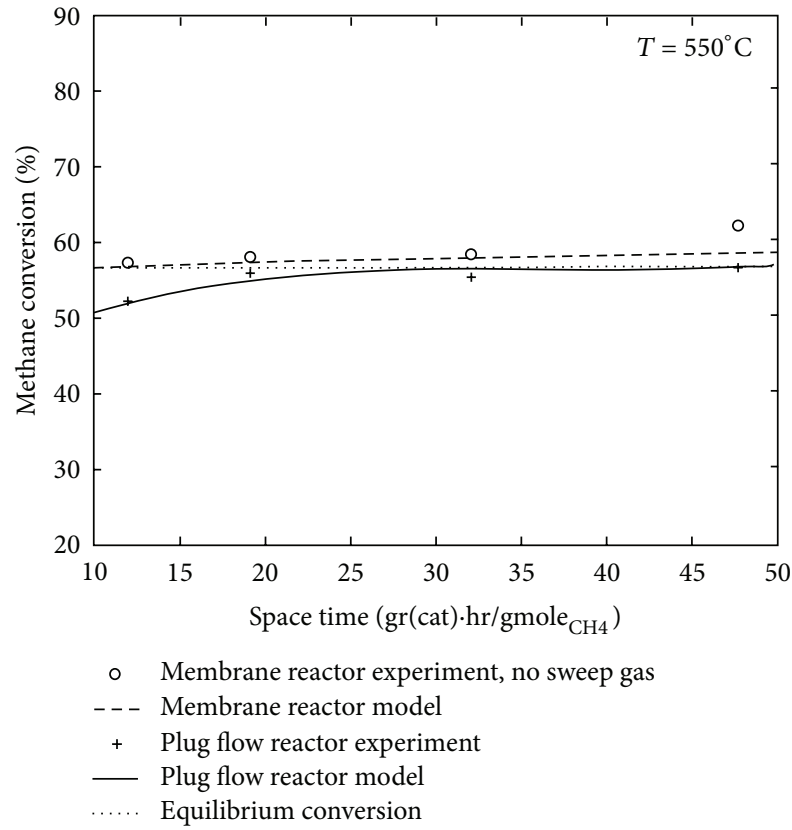

FIGURE 3: Experimental and modeling results of landfill gas-steam reformers for syngas production and SOFC continuous operation. Total methane conversion data $\left(P_{T_{o}}=1.68 \mathrm{~atm}\right.$, feed composition: $\mathrm{CH}_{4}: \mathrm{H}_{2} \mathrm{O}: \mathrm{H}_{2}=1: 4: 0.2$.

this way, the flow rate of the fuel-gas product going into the fuel cell/SOFC system is maximized based on reactions (5).

Figure 3 next shows the effect of the space time of the reactor on the methane conversion.

The temperature is fixed at $550^{\circ} \mathrm{C}$. The membrane reactor offers better conversions and yields than the nonmembrane reactor as also shown in Figures 3 and 4 . The membrane reactor conversions are showed to exceed the conventional catalytic plug-flow-reactor conversions for all the space times examined in this experiment. This is attributed to the effect of the membrane. The membrane offers primarily the separation of hydrogen, an effect that increases the conversion above the equilibrium conversion. The computational model described above agrees well with the membrane reactor data and the conventional catalytic plug-flow reactor data. Both the experimental membrane reactor yield data and the model are higher than the plug-flow reactor data and the equilibrium calculated $\mathrm{CO}_{2}$ yield data.

It is characteristic that most of the points taken with the membrane reactor operation exceed in methane conversion measure the corresponding points taken under regular plug flow reactor operation. We should point out that both reactors

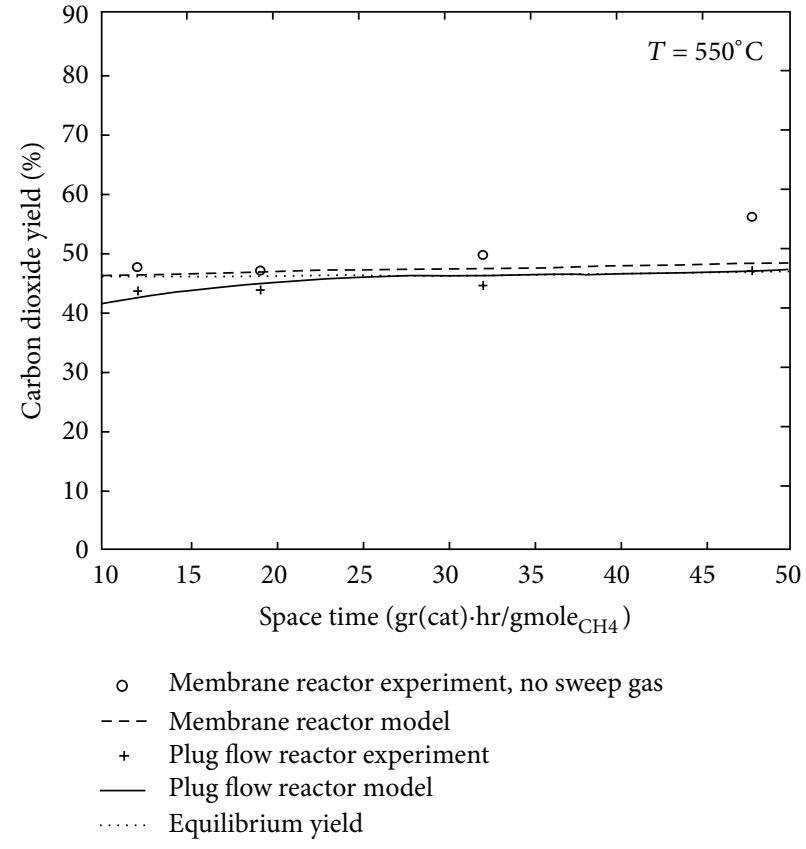

FIGURE 4: Experimental and modeling results of landfill gas-steam reformers for syngas production and SOFC continuous operation. Carbon dioxide yield data $\left(P_{T_{o}}=1.68 \mathrm{~atm}\right.$, feed composition: $\left.\mathrm{CH}_{4}: \mathrm{H}_{2} \mathrm{O}: \mathrm{H}_{2}=1: 4: 0.20\right)$.

are catalytic and are filled with catalyst particles. Also we should point out that the alumina-based membrane used in these experiments was blank (not rendered catalytic). It is also characteristic that the membrane reactor points exceed the equilibrium conversion calculated at the respective reaction side conditions. Moreover, the computational model described earlier, which simulates the membrane-reactor operation shows a good agreement with the experimentally measured membrane methane conversions and $\mathrm{CO}_{2}$ yields under the same reaction conditions. Thus, the membrane reformer is operation show to be beneficial in producing more synthesis gas (a mixture of hydrogen and carbon oxides) than the counterpart conventional plug flow reformer.

We are also presenting below two figures relating with the modeling and simulation of the methane/landfill gas-steam reforming reactor. We have used the model of (6), (8), (9), and (11) to simulate the permeable reformer [10]. PBMR in these plots, stands for a packed bed membrane reactor.

Next, Figure 5 shows the dimensionless molar flow rate of hydrogen, steam, and methane along the reaction side or tubeside of the membrane reactor. The molar flow rate for hydrogen passes through a maximum at about the middle 


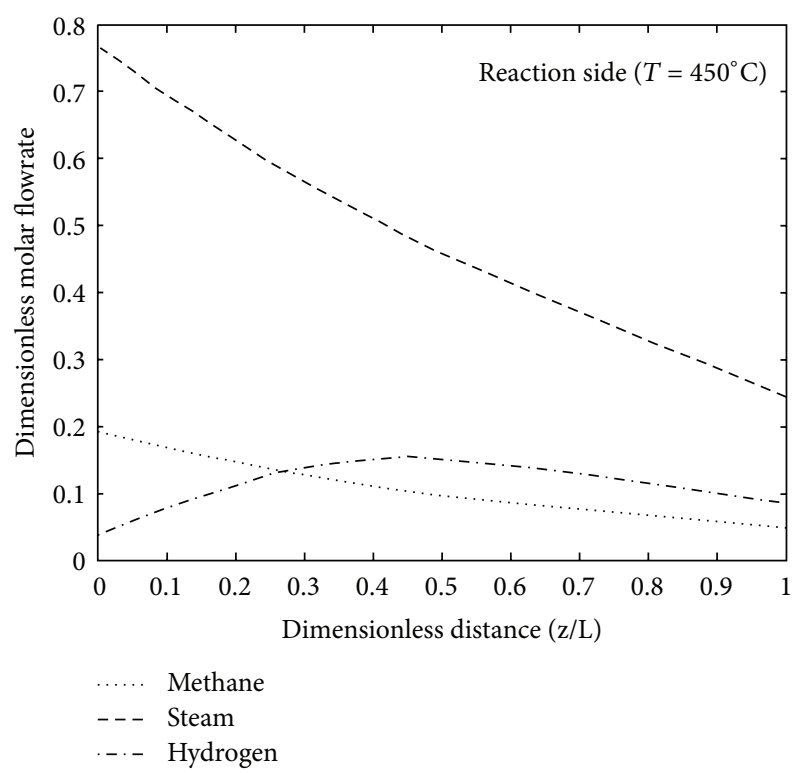

FIGURE 5: Modeling results of landfill gas-steam reformers for syngas production and SOFC continuous operation. Molar flowrate data in the reaction side (tubeside) $\left(P_{T_{o}}=1.68 \mathrm{~atm}\right.$, feed composition: $\mathrm{CH}_{4}$ : $\left.\mathrm{H}_{2} \mathrm{O}: \mathrm{H}_{2}=1: 4: 0.20\right)$.

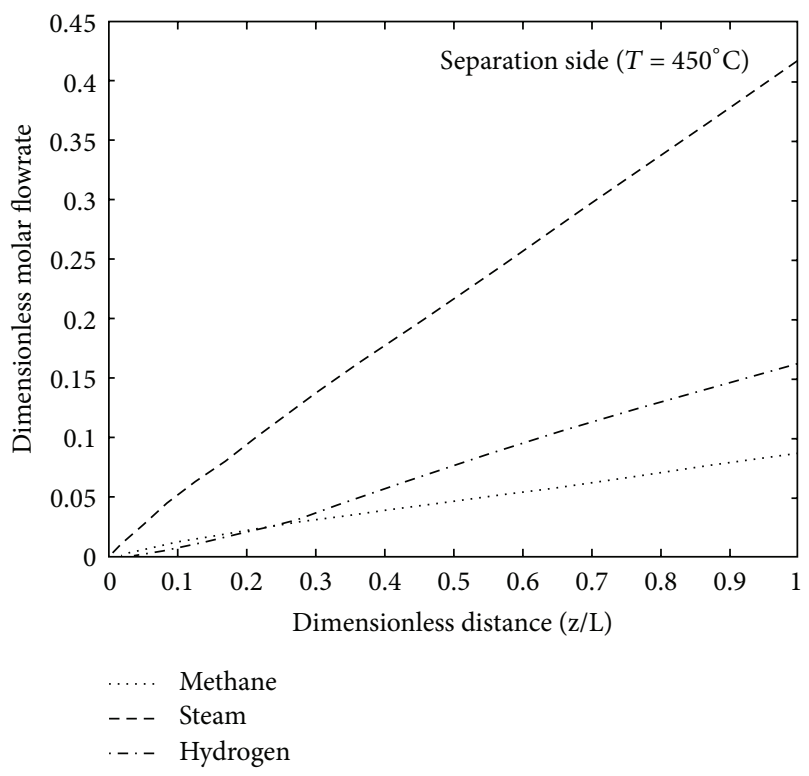

FIgURE 6: Modeling results of landfill gas-steam reformers for syngas production and SOFC continuous operation. Molar flowrate data in the separation side $\left(P_{T_{0}}=1.68 \mathrm{~atm}\right.$, feed composition: $\left.\mathrm{CH}_{4}: \mathrm{H}_{2} \mathrm{O}: \mathrm{H}_{2}=1: 4: 0.20\right)$.

axial length of the reactor. The molar flowrates for steam and methane decrease monotonically along the axial length of the reactor.

Figure 6 shows the dimensionless molar flow rate of hydrogen, steam, and methane along the separation side or shellside of the membrane reactor. In this case, the molar flow

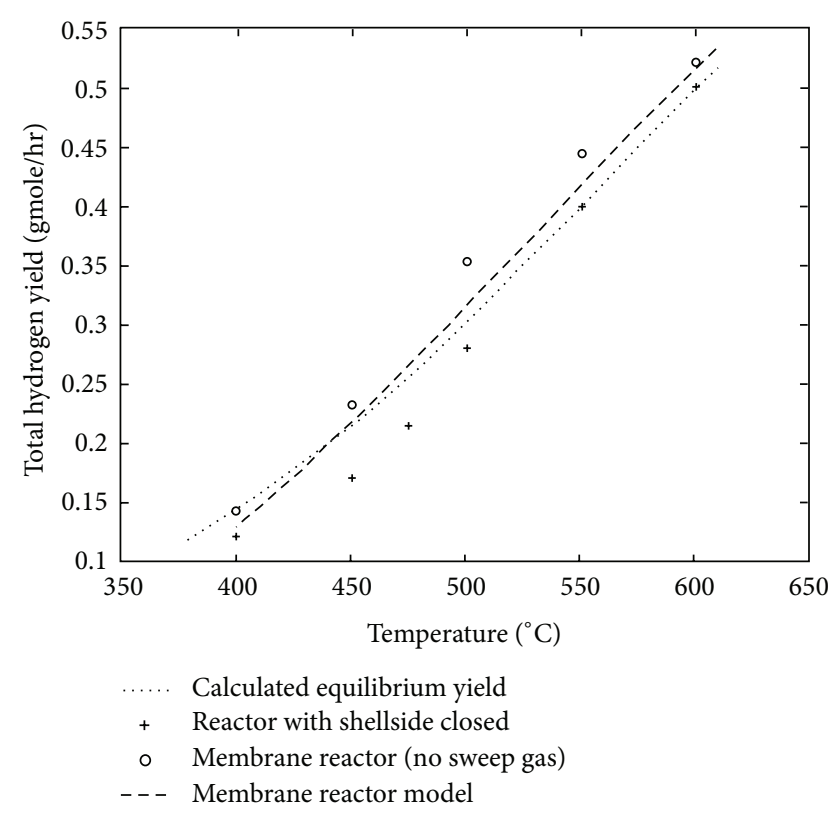

FIgURE 7: Experimental and modeling results of landfill gas-steam reformers for syngas production and SOFC continuous operation. Total hydrogen yield data.

rates for hydrogen, steam, and methane increase monotonically along the axial length of the reactor.

Finally, Figure 7 shows the combined hydrogen yield obtained with the two types of reactors. The membrane type reformer offers better hydrogen yields than the nonmembrane type reformer. This is shown both with the experimental and modeling results in Figure 7. It is therefore beneficial to use the membrane reformer in the flow chart of this process to accomplish the operation.

Moreover, Table 1 below shows a summary of specifications from a landfill-gas-processing plant for energy cogeneration (landfill gas is coming from a concentrated landfill site [16]). The table provides details on the energetic distribution outcome of the entire plant. This table is given for comparison purposes, in order to evaluate the potential of the newly described landfill gas to SOFC unit using the described membrane reactor and conventional reactor technologies. It is characteristic that the installed fuel cell/SOFC can provide electricity at a higher degree of efficiency than the respective gas engine or gas turbine.

\section{Conclusions}

It is shown here that high temperature SOFCs/fuel cells can be combined with reforming operations of landfill-based gases. The referred SOFCs systems can operate in series or are integrated with a catalytic reformer or membrane reformer which convert landfill gas into fuel-gas product at various operating conditions. To be more specific, these feedstock gases are rich in $\mathrm{CH}_{4}$ and are converted into an $\mathrm{H}_{2}, \mathrm{CO}$, and $\mathrm{CO}_{2}$ mixture suitable for the continuous operation of the SOFC unit. The reformers studied here have been 


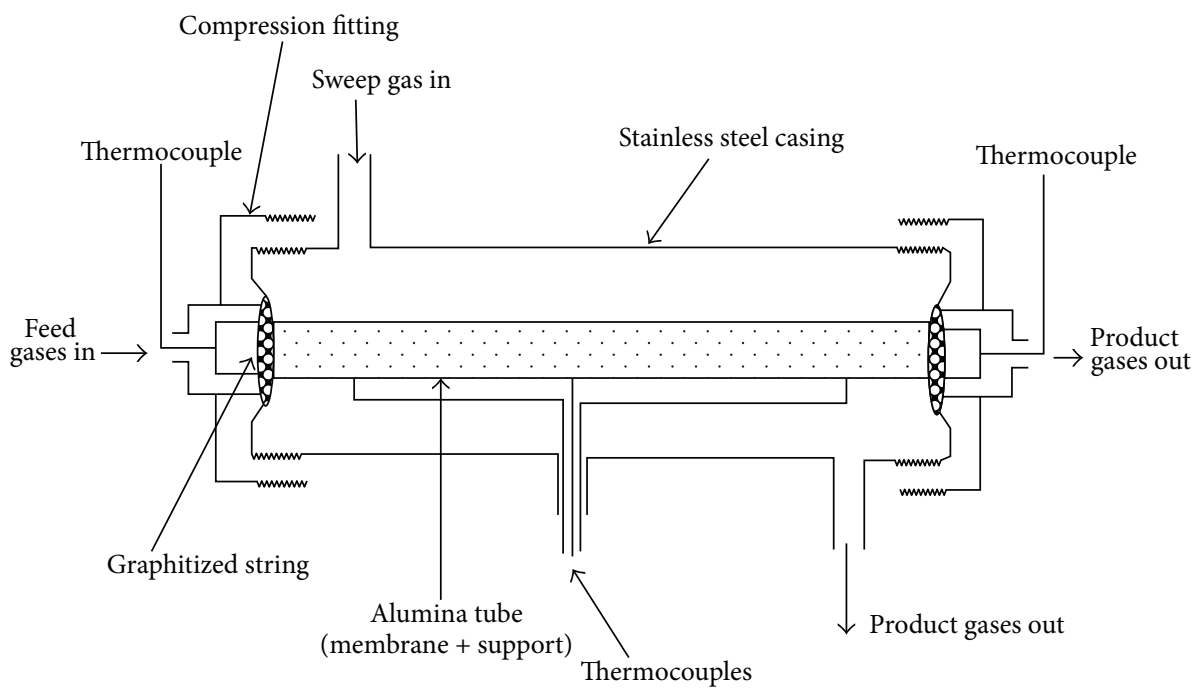

Figure 8: Ceramic membrane reactor.

also studied by computational models taking into account the reaction and hydrogen separation in the permeable reformers. Essential operating conditions in the permeable reformers have been simulated by the mathematical models. The experimental membrane reformer shows to offer higher yields than the nonmembrane type reformer for a number of operating conditions.

It is worthy to notice that important distributed power generation within a wider power grid can be accomplished with this operation, being able to cover the local needs of municipal and remote areas. Fuel cell power relates to the reformer conversion and the efficient utilization of the syngas by the fuel cell. The waste heat from the conversion of syngas to electricity can be descreased through the fuel cell operation and specifically through the operation of high efficiency SOFCs. Fuel cell (SOFCs) continuous operation and power generation from landfill gas can lead to pollution minimization, higher power density, and increased efficiency (reduced waste heat) in comparison with conventional power systems.

\section{References}

[1] Z. Ziaka and S. Vasileiadis, "Catalytic reforming -shift processors for hydrogen generation and continuous fuel cell operation," in Proceedings of IASTED-Power and Energy Systems, pp. 360-365, Marina Del Ray, Calif, USA, May 2002.

[2] S. Vasileiadis and Z. Ziaka-Vasileiadou, "Biomass reforming process for integrated solid oxide-fuel cell power generation," Chemical Engineering Science, vol. 59, no. 22-23, pp. 4853-4859, 2004.

[3] S. Vasileiadis and Z. Ziaka, "Alternative generation of $\mathrm{H}_{2}, \mathrm{CO}$ and $\mathrm{H}_{2}, \mathrm{CO}_{2}$ mixtures from steam-carbon dioxide reforming of methane and the water gas shift with permeable (membrane) reactors," Chemical Engineering Communications, vol. 176, pp. 247-252, 1999.
[4] J. Xu and G. F. Froment, "Methane steam reforming, methanation and water-gas shift: I. Intrinsic kinetics," AIChE Journal, vol. 35, no. 1, pp. 88-96, 1989.

[5] J. P. van Hook, "Methane-steam reforming," Catalysis Reviews: Science and Engineering, vol. 21, no. 1, pp. 1-51, 1980.

[6] J. R. Rostrup-Nielsen, "Sulfur-passivated nickel catalysts for carbon-free steam reforming of methane," Journal of Catalysis, vol. 85, no. 1, pp. 31-43, 1984.

[7] J. R. Rostrup-Nielsen, "Coking on nickel catalysts for steam reforming of hydrocarbons," Journal of Catalysis, vol. 33, no. 2, pp. 184-201, 1974.

[8] J. T. Richardson and S. A. Paripatyadar, "Carbon dioxide reforming of methane with supported rhodium," Applied Catalysis, vol. 61, no. 1, pp. 293-309, 1990.

[9] E. Ruckenstein and Y. H. Hu, "Combination of $\mathrm{CO}_{2}$ reforming and partial oxidation of methane over $\mathrm{NiO} / \mathrm{MgO}$ solid solution catalysts," Industrial \& Engineering Chemistry Research, vol. 37, no. 5, pp. 1744-1747, 1998.

[10] Z. D. Ziaka and S. P. Vasileiadis, Reactors for Fuel Cells and Environmental Energy Systems, Xlibris Publishing, Indianapolis, Ind, USA, 2009.

[11] S. P. Vasileiadis and Z. D. Ziaka, "Environmentally benign hydrocarbon processing applications of single and integrated permreactors," in Reaction Engineering for Pollution Prevention, pp. 247-304, Elsevier Science, Philadelphia, Pa, USA, 2000.

[12] Z. D. Ziaka and S. P. Vasileiadis, "Reactor-membrane permeator cascade for enhanced production and recovery of $\mathrm{H} 2$ and $\mathrm{CO} 2$ from the catalytic methane-steam reforming reaction," Chemical Engineering Communications, vol. 156, pp. 161-200, 1996.

[13] D. L. Klass, Biomass for Renewable Energy, Fuels, and Chemicals, Academic Press, San Diego, Calif, USA, 1988.

[14] S. Vasileiadis and Z. Ziaka, "Efficient catalytic reactors-processors for fuel cells and synthesis applications," in Proceedings of the 17th International Symposium on Chemical Reaction Engineering, Hong Kong, August 2002, paper no. 13. 
[15] R. Rautenbach and K. Welsch, "Treatment of landfill gas by gas permeation-pilot plant results and comparison to alternatives," Journal of Membrane Science, vol. 87, no. 1-2, pp. 107-118, 1994.

[16] M. Tsimpa, Biogas usages in Greece for energy generation, trends and opportunities [M.S. thesis], Hellenic Open University, Patras, Greece, 2010. 


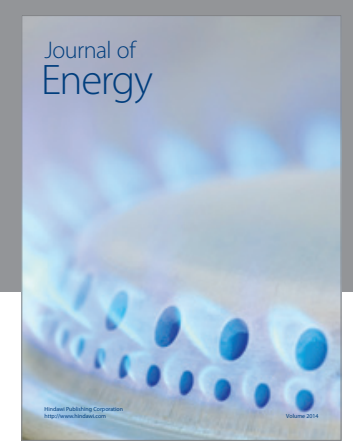

Journal of

Industrial Engineering
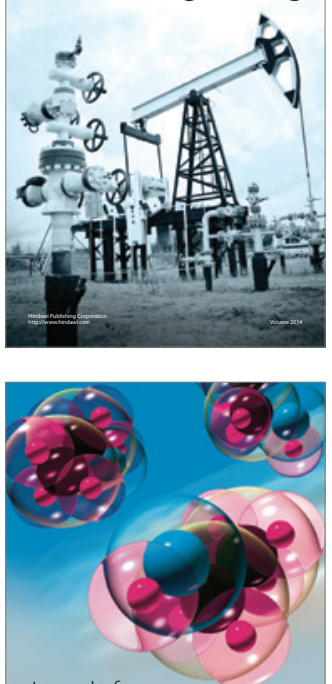

Fuels
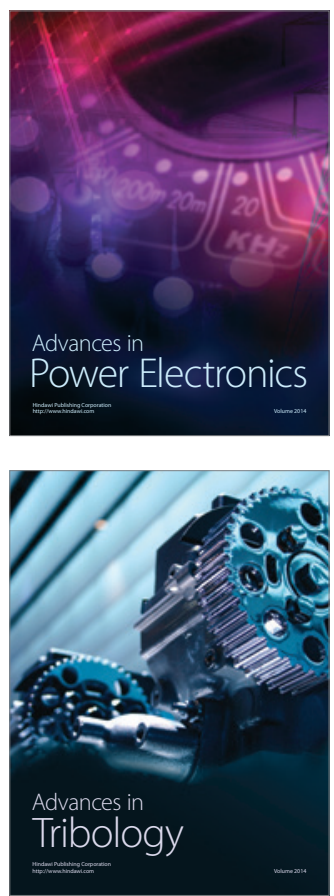

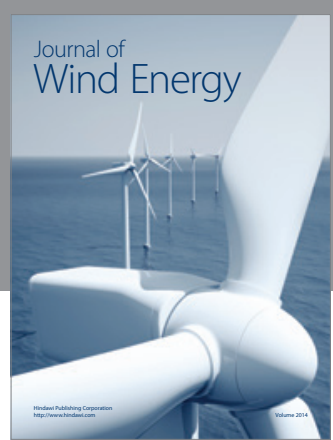

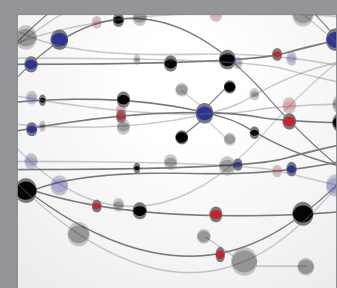

The Scientific World Journal

Submit your manuscripts at http://www.hindawi.com

Journal of

Structures
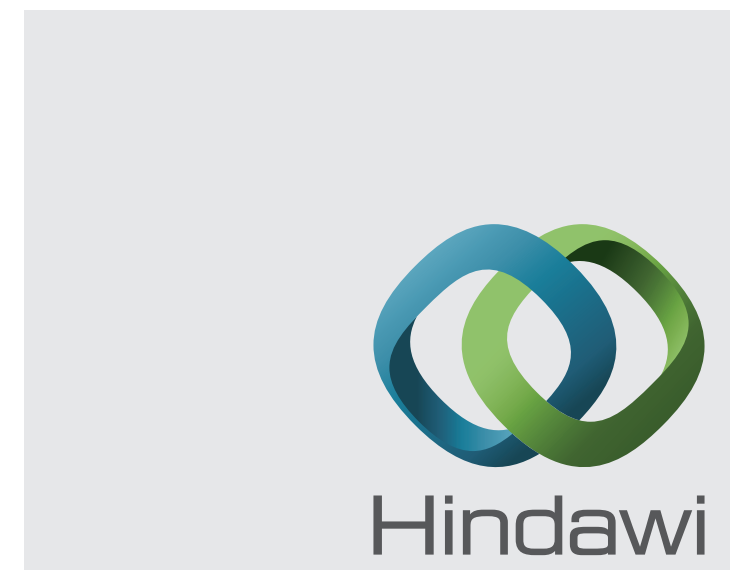

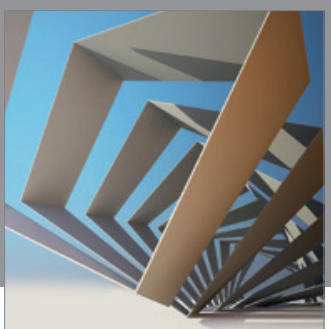

Rotating

Machinery
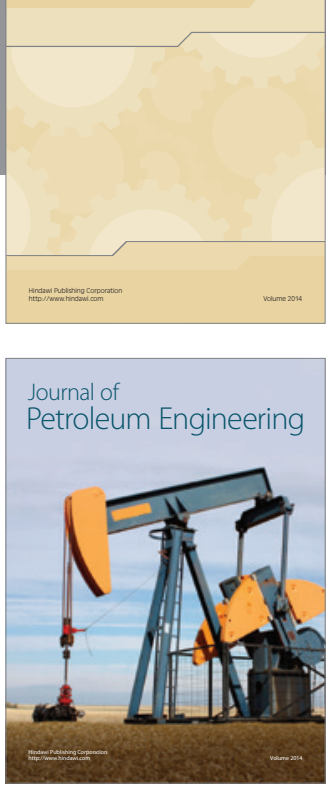

Journal of

Solar Energy
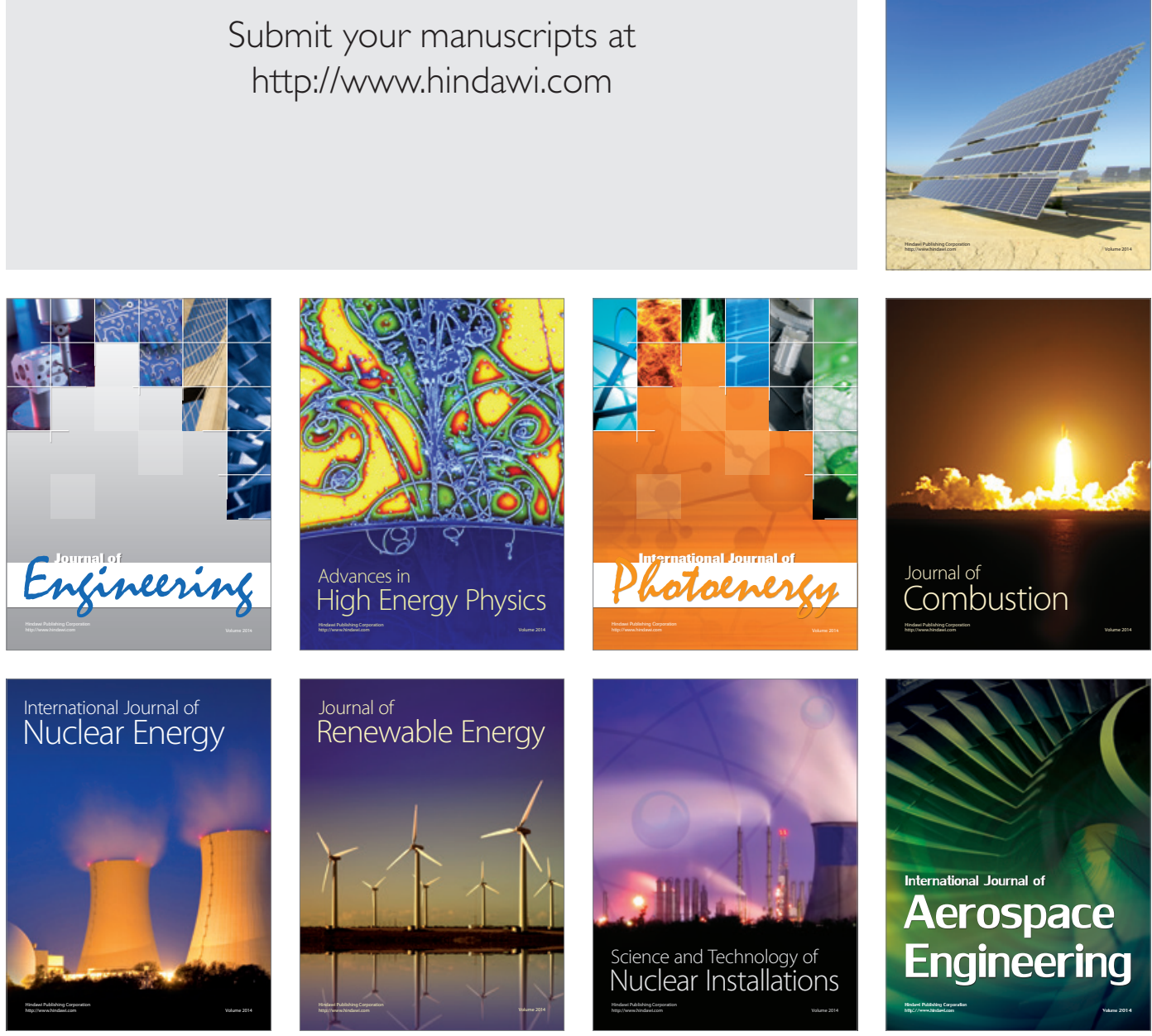